\title{
Vulnerability of romanian children with type 1 diabetes to emotional and behavioral disorders towards family support
}

KÁLCZA-JÁNOSI KINGA ${ }^{1}$

JÁNOS HENRIETTA TIMEA ${ }^{2}$

LUKÁCS ANDREA ${ }^{3}$

\begin{abstract}
In this study we explore the vulnerability of children with Type 1 diabetes to emotional and behavioral disorders, focusing on the effect of diabetes family support on the physical and psychological well-being of these patients. A total of 20 children with Type 1 diabetes from Romania participated in this study. As measuring tool we used Child Behavior Checklist for detecting the symptoms of emotional and behavioral disorders, and the diabetes family support was evaluated with the Diabetes Social Support Questionnaire- Family version. Our data revealed diabetes specific emotional support as being the most significant in mediating the probability of emotional and behavioral problems.
\end{abstract}

\section{Keywords}

Type 1 diabetes, children, anxiety/depression, social problems, emotional support

1. PhD, Babes-Bolyai University, Faculty of Psychology and Educational Sciences, Department of Applied Psychology, Cluj-Napoca, Romania.

2. Babes-Bolyai University, Faculty of Psychology and Educational Sciences, Department of Applied Psychology, Cluj-Napoca, Romania

Address for correspondence: 128 December 21, 1989 Boulevard, Cluj Napoca, Cluj; Tel.:

+40264-445206; E-mail address: henrietta.janos@ubbcluj.ro

3. PhD, University of Miskolc, Faculty of Health Care, Miskolc, Hungary 


\section{References}

Abdul-Rasoul, M., Hajiyya, J., Alshawaf, F., Abdal, Y., Al-Azmni, A., Al-Mahdi, M.(2010).Psychological status of children with type 1 diabetes in Kuwait. KuwaitMed. J. 42, 139- 145.

Anderson, B.J., Auslander, W.F., Jung, K.C., Miller, J.P., Santiago, J.V.(1990).Assessing family sharing of diabetes responsibilities. J Pediatr Psychol 15,477-492.

Anderson, B., Ho, J., Brackett, J., Finkelstein, D., Laffel, L. (1997). Parental involvement in diabetes management tasks: relationships to blood glucose monitoring adherence and metabolic control in young adolescents with insulin-dependent diabetes mellitus. J Pediatr 130, 257-265

Anderson, B.J., Brackett, J., Ho, J., Laffel, L. (1999). An office-based intervention to maintain parent-adolescent teamwork in diabetes management: impact on parent involvement, family conflict, and subsequent glycemic control. Diabetes Care 22, 713-721.

Andreica, M., Miu, N., Andreica-Săndică, B., Rauca, I. (2008). Diabetul zaharat tip I., În M. Andreica, B. Andreica-Săndică: Boli cronice și aspecte psihosomatice la copil (pp.71-117). Casa Cărții de Știință, Cluj Napoca.

Buchberger, B., Huppertz, H., Krabbe, L., Lux, B., Mattivi, J. T., Siafarikas, A. (2016). Symptoms of depression and anxiety in youth with type 1 diabetes: A systematic review and meta-analysis. Psychoneuroendocrinology 70, 70-84.

Burns, K.L., Green, P., Chase, H.P. (1986). Psychosocial correlates of glycemic control as a function of age in youth with IDDM. J Adoles Health Care 7,311-319

Cameron, F.J., Northam, E.A., Ambler, G.R., Daneman, D (2007).Routinepsychological screening in youth with type 1 diabetes and their parents: anotion whose time has come?. Diabetes Care 30, 2716-2724.

Cohen, D.M., Lumley, M.A., Naar-King, S., Partridge, T., Cakan, N. (2004) Child behavior problems and family functioning as predictors of adherence and glycemic control in economically disadvantaged children with Type $1 \mathrm{di}-$ abetes: a prospective study. J Pediatr Psychol 29, 171-184. Comer, R. J. (2005). A lélek betegségei, pszichopatológia. Budapest: Osiris Kiadó. 
De Wit, M., Snoek, F.J. (2011). Depressive symptoms and unmet psychological needs of Dutch youth with type 1 diabetes: results of a websurvey. Pediatr. Diabetes12, 172-176.

Fisher, L., Hessler, D.M., Polonsky, W.H., Mullan. J. (2012). When is diabetes distress clinically meaningful? Establishing cut points for the Diabetes Distress Scale. Diabetes Care 35: 259-264. In: American Diabetes Association (ADA) (2016). Standards of Medical Care in Diabetes, Diabetes Care, 39(1), S23-S35.

Goldston, D.B., Kelley, A.E., Reboussin, D.M., Daniel, S.S., Smith, J.A., Schwartz, R.P., Lorentz, W., Hill, C. (1997). Suicidal ideation and behaviour and noncompliance with the medical regimen among diabetic adolescents. J Am Acad Child Adol Psychiatry 36, 1528-1536.

Herzer, M., Hood, K.K.(2010). Anxiety symptoms in adolescents with type 1diabetes: association with blood glucose monitoring and glycemic control. J.Pediatr. Psychol. 35, 415-425.

Herzer, M., Vesco, A., Ingerski, L.M., Dolan, L.M., Hood, K.K. (2011). Explaining thefamily conflict-glycemic control link through psychological variables inadolescents with type 1 diabetes. J. Behav. Med. 34, 268-274.

Hilliard, M.E., Herzer, M., Dolan, L.M., Hood, K.K. (2011). Psychological screening inadolescents with type 1 diabetes predicts outcomes one year later. DiabetesRes. Clin. Pract. 94, 39-44.

Hood, K.K., Rausch, J.R., Dolan, L.M.(2011). Depressive symptoms predict change inglycemic control in adolescents with type 1 diabetes: rates, magnitude, andmoderators change. Pediatr. Diabetes 12, 718-723.

Ingersoll, G.M., Orr D.P., Herrold, A.J., Golden, M.P. (1986). Cognitive maturity and self-management among adolescents with insulin-dependent diabetes mellitus. J Pediatr 108, 620-623

Khan, W.I., Rabbani, M.W., Afzal, E., Adnan, M.(2013). Psychological screening inchildren with diabetes mellitus type-I at the children's hospital and theInstitute of Child Health, Multan. J. Pak. Med. Assoc. 63, 1520-1522

Kovacs, B. K., Nicolucci, A., Holt, RIG, et al.; DAWN2 Study Group. (2013). Diabetes Attitudes, Wishes and Needs second study (DAWN2): crossnational benchmarking indicators for family members living with people with diabetes. Diabet Med 30,778-788 
Kovacs, M., Obrosky, D.S., Goldston, D., Drash, A. (1997) Major depressive disorder in youths with IDDM: a controlled prospective study of course and outcome. Diabetes Care 20, 45-51.

Kristensen, L.J., Birkebaek, N.H., Mose, A.H., Hohwü, L., Thastum, M. (2014).Symptoms of emotional, behavioral, and social difficulties in the danishpopulation of children and adolescents with type 1 diabetes-results of anational survey. PLoS One 9: e97543

Liss, D.S., Waller, D.A., Kennard, B.D., McIntire, D., Capra, P., Stephens, J. (1998) Psychiatric illness and family support in children and adolescents with diabetic ketoacidosis: a controlled study. J Am Acad Child Adolesc Psychiatry37, 536-544

McGrady, M.E., Hood, K.K. (2010). Depressive symptoms in adolescents with typeldiabetes: associations with longitudinal outcomes. Diabetes Res. Clin. Pract.88, e35-e37.

Nicolucci, A., Kovacs, B. K., Holt, RIG, et al.; DAWN2 Study Group. (2013).Diabetes Attitudes, Wishes and Needs second study (DAWN2): crossnational benchmarking of diabetes-related psychosocial outcomes for people with diabetes. Diabet Med 30, 767-777

Rewers, M.J., Pillay, K., de Beaufort, C., Craig, M.E., Hanas, R., Acerini, C.L., Maahs, D.M. Assessment and monitoring of glycemic control in children and adolescents with diabetes. Pediatric Diabetes 2014: 15 (Suppl. 20): 102-114.

Weissberg-Benchell, J., Glasgow, A.M., Tynan, W.D., Wirtz, P., Turek, J., Ward, J. (1995). Adolescent diabetes management and mismanagement. Diabetes Care18, 77-82.

Wysocki, T., Taylor, A., Hough, B.S., Linsheid, T.R., Yeates, K.O., Naglieri, J.A. (1996). Deviation for developmentally appropriate self-care autonomy. Association with diabetes outcomes. Diabetes Care 19, 119-125. 